\title{
PERANCANGAN ALMARI PAKAIAN BAYI SERBAGUNA MELALUI BRAINSTORMING DENGAN IBU RUMAH TANGGA
}

\author{
MOCHAMMAD ROFIEQ \\ Jurusan Teknik Industri Universitas Merdeka Malang \\ E-mail: mfieq@yahoo.com
}

\begin{abstract}
ABSTRAK
Tujuan dirancangnya almari pakaian bayi serba guna adalah untuk memberikan kemudahan dalam memenuhi kebutuhan para ibu yang memiliki bayi. Almari ini dirancang untuk berbagai kebutuhan, antara lain sebagai tempat pakaian, perlengkapan mandi dan perlengkapan minum (termos air panas, teko air dingin, kaleng susu, botol susu) serta agar para ibu tidak perlu repot menyiapkan minuman bayi pada waktu malam hari. Teknik yang digunakan dalam pengembangan alternatif adalah melalui brainstorming. Penggunaan teknik ini dengan cara mengumpulkan beberapa masukan yang diperoleh dari para ibu rumah tangga yang telah memiliki bayi, calon ibu yang akan melahirkan bayinya dan suster yang ada di rumah bersalin. Dari masukan yang diperoleh melalui brainstorming dibuat suatu peta morfologi yang berguna untuk memilih alternatif terbaik dalam merancang produk almari pakaian bayi serbaguna.
\end{abstract}

Kata kunci: almari pakaian bayi, brainstorming, peta morfologi

\begin{abstract}
Goal of designing baby cupboard is to make easy for the young mother that have a baby. It designed for any needs, example as place of clothes, tools of bath and tools of drink (thermos, teapot, milk, bottle), and in order to them not difficult to prepare baby's drink in the night. The technics has made to develop alternative is brainstorming. It used with collecting some suggestion from young mother that have a baby, mother to be and susters are in the hospital. From the result with this brainstorming made a Morfology Chart that use to choose the best alternative to design the baby cupboard product.
\end{abstract}

Key words: baby cupboard, brainstorming, morfology chart

\section{PENDAHULUAN}

Perancangan dan pengembangan suatu produk merupakan aktivitas yang sangat penting untuk dilakukan, karena hal ini terkait erat dengan aspek fungsional yang diinginkan konsumen dimiliki produk tersebut. Ada empat klasifikasi produk atas dasar sikap pembeli (Inwood and Hammond, 1995): (1) Produk kesenangan, sering dibeli, segera dan dengan sedikit usaha dalam pembandingan dan pembelian. Kemudahan memperoleh produk dan daya tarik yang kuat pada panca indera lebih penting ketimbang sifat produk, (2) Produk belanjaan, adalah produk yang dalam proses pemilihan dan pembelian dibandingkan oleh pelanggan atas dasar kecocokan mutu, harga dan desain, (3) Produk istimewa, memiliki sifat unik dan/atau identifikasi merek yang dengan demikian sekelompok pembeli khusus biasanya bersedia mengadakan usaha pembelian khusus, (4) Produk yang tidak dicari, adalah produk yang tidak dikenal oleh pelanggan atau yang dikenal tetapi biasanya pelanggan tidak terpikir untuk membelinya. Kotler (1988) menerapkan klasifikasi tersebut pada produk konsumen, tetapi juga dapat diterapkan pada barang yang dibeli oleh industri dan profesional.

Enam fase yang perlu dilakukan dalam proses pengembangan suatu produk (Ulrich and Eppinger, 2001) adalah: (1) Fase 0: Perencanaan, kegiatan perencanaan sering dirujuk sebagai 'zero fase' karena kegiatan ini mendahului persetujuan proyek dan proses peluncuran pengembangan produk aktual, (2) Fase 1: Pengembangan konsep, pada fase pengembangan konsep, kebutuhan pasar target diidentifikasi, alternatif konsep-konsep produk dibangkitkan dan dievaluasi, dan satu atau lebih konsep dipilih untuk pengembangan dan percobaan lebih jauh, (3) Fase 2: Perancangan tingkatan sistem, fase perancangan tingkatan sistem mencakup definisi arsitektur produk dan uraian produk menjadi subsistem-subsistem serta komponen-komponen, (4) Fase 3: Perancangan detail, fase perancangan detail mencakup spesifikasi lengkap dari bentuk, material, dan toleransi-toleransi dari seluruh komponen unik pada produk dan identifikasi 
seluruh komponen standar yang dibeli dari pemasok, (5) Fase 4: Pengujian dan perbaikan, fase pengujian dan perbaikan melibatkan konstruksi dan evaluasi dari bermacam-macam versi produksi awal produk, (6) Fase 5: Produksi awal, pada fase produksi awal, produk dibuat dengan menggunakan sistem produksi yang sesungguhnya. Tujuan dari produksi awal ini adalah untuk melatih tenaga kerja dalam memecahkan permasalahan yang mungkin timbul pada proses produksi sesungguhnya.

Dari seluruh teknik berfikir kreatif, brainstorming adalah salah satu teknik yang dapat digunakan secara umum dan dapat digunakan dalam banyak bidang. Teknik brainstorming mula-mula dikembangkan oleh Alex F. Osborn pada tahun 1930-an. Osborn dalam Zaman (2011) mengatakan bahwa brainstorming berarti penyerbuan dengan ide-ide yang sebanyak mungkin terhadap suatu masalah dilangsungkan dalam suatu pertemuan. Brainstorming dapat didefinisikan sebagai satu cara untuk mendapatkan banyak ide dari sekelompok manusia dalam waktu yang sangat singkat. Brainstorming biasanya merupakan aktivitas kelompok yang menghasilkan sejumlah besar ide. Sekelompok manusia tidak hanya akan saling melengkapi dalam pengalaman yang luas, tetapi juga menjamin pertukaran ide dan saling mengisi. Dalam hal demikian, ide seseorang akan menolong merangsang ide orang lain dan akhirnya menjadi arus ide yang nyata (Rawlinson, 1986).

Dalam suatu rumah tangga sering dijumpai seorang ibu yang memiliki bayi begitu repot dalam merawat dan mempersiapkan semua perlengkapan bayinya. Mulai dari perlengkapan mandi, bedak, minyak telon/kayu putih, pakaian, sampai pada saat harus membuatkan minuman susu hangat di malam hari. Ibu tersebut begitu repot karena semua perlengkapan tersebut tidak terletak di satu tempat melainkan tersebar di sana sini bahkan ada yang berada di luar kamar.

Tujuan dari penelitian ini adalah merancang almari pakaian bayi yang serbaguna. Karena almari ini dirancang dengan tujuan untuk berbagai kebutuhan yakni sebagai tempat penyimpanan pakaian bayi, tempat penyimpanan popok bayi, tempat penyimpanan perlengkapan mandi bayi, tempat penyimpanan sepatu bayi, tempat pembuatan susu bayi, serta di bagian atas almari digunakan untuk meletakkan termos air panas, teko air dingin, kaleng susu dan tissue. Beberapa manfaat yang dapat diperoleh dengan dirancangnya almari pakaian bayi serbaguna ini adalah para ibu tidak perlu repot lagi dalam merawat dan menyiapkan keperluan bayinya khususnya pada waktu malam hari. Sedangkan ditinjau dari segi ekonomi dapat memberikan kemudahan bagi para ibu yang memiliki bayi karena harganya terjangkau dan mudah digunakan.

\section{METODE}

Teknik yang digunakan dalam mengumpulkan data kebutuhan pengguna almari pakaian bayi (konsumen) adalah melalui brainstorming. Penggunaan brainstorming dalam penelitian ini dilakukan dengan cara mengumpulkan sepuluh orang wanita yang terdiri atas ibu rumah tangga yang telah memiliki bayi, calon ibu yang akan melahirkan bayinya dan suster rumah bersalin untuk melakukan diskusi dan bertukar pikiran tentang penilaian mereka terhadap hal-hal yang tidak disukai dari almari pakaian bayi yang selama ini ada serta atribut/fungsi tambahan apa saja yang diharapkan ada pada almari pakaian bayi serbaguna yang akan dirancang.

Dari berbagai masukan dan ide yang diperoleh melalui brainstorming, diinterpretasikan menjadi pernyataan kebutuhan konsumen. Langkah berikutnya adalah membuat klasifikasi terhadap usulan perbaikan produk almari pakaian bayi yang hendak dirancang dalam bentuk diagram, menggambarkan aspek fungsional almari pakaian bayi dalam sistem black box, kemudian mengembangkan aspek fungsional tersebut lebih rinci, di mana fungsi meletakkan dan menyimpan perlengkapan bayi perlu dipilah-pilah menjadi beberapa fungsi yang lebih detail sehingga proses input menjadi output menjadi lebih jelas (sistem white box).

Langkah selanjutnya adalah membuat peta morfologi yang berguna untuk memilih alternatif terbaik dalam merancang produk almari pakaian bayi serbaguna dan diakhiri dengan proses pembuatan produk almari pakaian bayi serbaguna tersebut dengan satu pintu almari utama dan tiga buah laci, bagian atas digunakan sebagai meja dan diberi tempat tissue, dilanjutkan dengan memberikan gantungan handuk di bagian samping serta proses finishing/ pengecatan dan penempelan cutting sticker.

\section{HASIL DAN PEMBAHASAN}

Hasil dari pernyataan pengguna almari pakaian bayi (konsumen) diinterpretasikan untuk mendapatkan pernyataan kebutuhan, sebagaimana ditunjukkan pada tabel 1 berikut. 
Tabel 1. Interpretasi Pernyataan Konsumen

\begin{tabular}{|c|c|}
\hline Pernyataan Konsumen & Pernyataan Kebutuhan \\
\hline \multicolumn{2}{|l|}{ Penggunaan Khusus } \\
\hline Dibutuhkannya tempat untuk menyimpan perlengkapan bayi & Almari sebagai tempat menyimpan pakaian bayi \\
\hline Dibutuhkannya meja sebagai tempat pembuatan susu bayi & $\begin{array}{l}\text { Bagian atas almari berfungsi sebagai meja tempat pembuatan } \\
\text { susu bayi }\end{array}$ \\
\hline $\begin{array}{l}\text { Dibutuhkannya meja sebagai tempat belajar atau rak buku anak, } \\
\text { pada saat anak sudah besar/sekolah }\end{array}$ & $\begin{array}{l}\text { Meja pada bagian atas almari dapat digunakan sebagai tempat } \\
\text { belajar atau rak buku anak, pada saat anak sudah besar/sekolah }\end{array}$ \\
\hline \multicolumn{2}{|l|}{ Yang disukai dari produk saat ini } \\
\hline Suka karena praktis & Almari mudah dalam hal penempatannya \\
\hline Suka karena tahan lama & Almari anti penyok, anti rayap dan anti jamur \\
\hline Suka karena sederhana & Almari terkesan simple \\
\hline \multicolumn{2}{|l|}{ Yang tidak disukai dari produk saat ini } \\
\hline Tidak suka karena tidak multifungsi & $\begin{array}{l}\text { Almari perlu dibuat dengan berbagai kegunaan (untuk } \\
\text { menyimpan pakaian, tempat minum, perlengkapan mandi). Saat } \\
\text { anak sudah besar/sekolah, almari dapat dipakai sebagai meja } \\
\text { belajar dan rak buku }\end{array}$ \\
\hline Tidak suka karena tidak fleksibel & Almari perlu dilengkapi dengan baut untuk knock down \\
\hline Tidak suka karena tidak mengandung unsur keindahan & $\begin{array}{l}\text { Almari perlu dibuat lebih menarik dengan dicat dan } \\
\text { diberi cutting sticker }\end{array}$ \\
\hline Tidak suka karena tidak dilengkapi dengan kunci pengaman & Almari perlu dilengkapi dengan kunci pengaman \\
\hline \multicolumn{2}{|l|}{ Saran Perbaikan } \\
\hline Almari dibuat praktis & $\begin{array}{l}\text { Almari dibuat dalam ukuran yang mudah dalam penempatannya } \\
\text { (tidak terlalu besar), mudah dipindahkan dan dibongkar pasang }\end{array}$ \\
\hline Almari dibuat bisa tahan lama & $\begin{array}{l}\text { Almari dibuat dari bahan yang anti penyok, anti rayap dan anti } \\
\text { jamur }\end{array}$ \\
\hline Model almari diberi unsur keindahan dan keamanan & $\begin{array}{l}\text { Almari dicat dan diberi cutting sticker serta di bagian uama } \\
\text { almari diberi kunci pengaman }\end{array}$ \\
\hline Almari dibuat dari bahan dasar yang kuat & $\begin{array}{l}\text { Almari dibuat dengan menggunakan bahan dasar dari kayu } \\
\text { blackboard }\end{array}$ \\
\hline Diberi tempat untuk meletakkan handuk & $\begin{array}{l}\text { Di bagian samping almari diberi gantungan untuk meletakkan } \\
\text { handuk bayi }\end{array}$ \\
\hline $\begin{array}{l}\text { Diberi meja untuk membuat susu dan dapat digunakan sebagai } \\
\text { tempat belajar dan rak buku (saat anak sudah besar/sekolah) }\end{array}$ & $\begin{array}{l}\text { Di bagian atas almari dapat digunakan sebagai meja tempat } \\
\text { pembuatan susu serta tempat belajar dan rak buku saat anak } \\
\text { sudah besar/sekolah }\end{array}$ \\
\hline
\end{tabular}

Atas dasar pernyataan kebutuhan pengguna almari pakaian bayi yang diinterpretasikan dari pernyataan konsumen saat dilakukan brainstorming, dapat dikelompokkan ke dalam diagram pohon klasifikasi usulan perbaikan terhadap produk almari pakaian bayi yang hendak dirancang serbaguna sebagai berikut (lihat gambar 1).

Secara sederhana almari pakaian bayi dapat digambarkan dalam sebuah model sistem black box yang mengubah dan memberikan nilai tambah pada input menjadi output yang diinginkan (lihat gambar 2).

Untuk mengembangkan produk almari pakaian bayi perlu diketahui fungsi almari lebih rinci dan bukan sekedar black box. Oleh karena itu, fungsi meletakkan dan menyimpan perlengkapan bayi perlu dipilah-pilah menjadi beberapa fungsi yang lebih detail sehingga bagaimana proses input menjadi output menjadi lebih jelas (transparan). Fungsi almari dalam konteks model sistem white box dapat dikembangkan seperti pada gambar 3 . 


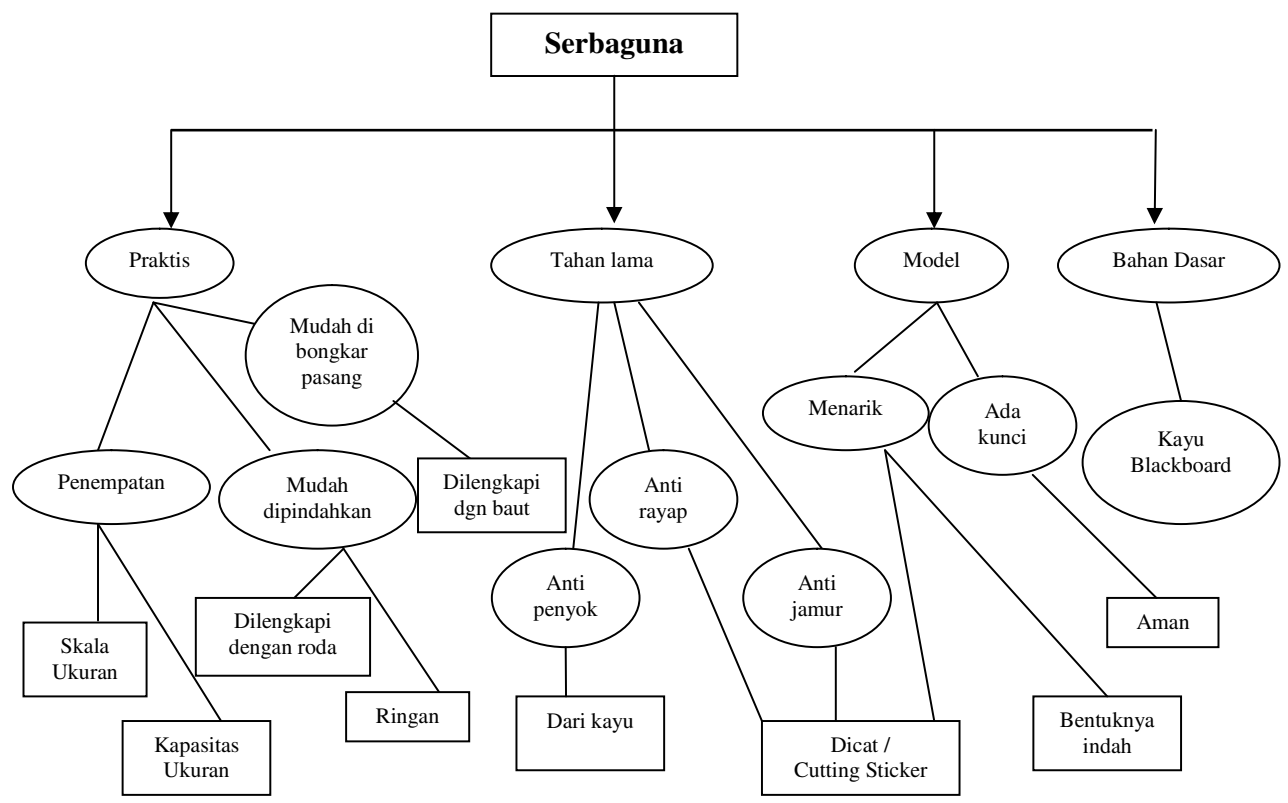

Gambar 1. Diagram Pohon Klasifikasi Usulan Perbaikan

\begin{tabular}{|c|c|c|}
\hline Perlengkapan bayi & \multirow{2}{*}{$\begin{array}{l}\text { Menyimpan pakaian, sepatu dan } \\
\text { perlengkapan mandi serta meletakkan } \\
\text { perlengkapan susu. Menyimpan buku } \\
\text { serta digunakan sebagai meja belajar }\end{array}$} & $\begin{array}{l}\text { Perlengkapan bayi } \\
\text { tertata rapi }\end{array}$ \\
\hline input & & output \\
\hline
\end{tabular}

Gambar 2. Sistem Black Box dari Almari Pakaian Bayi

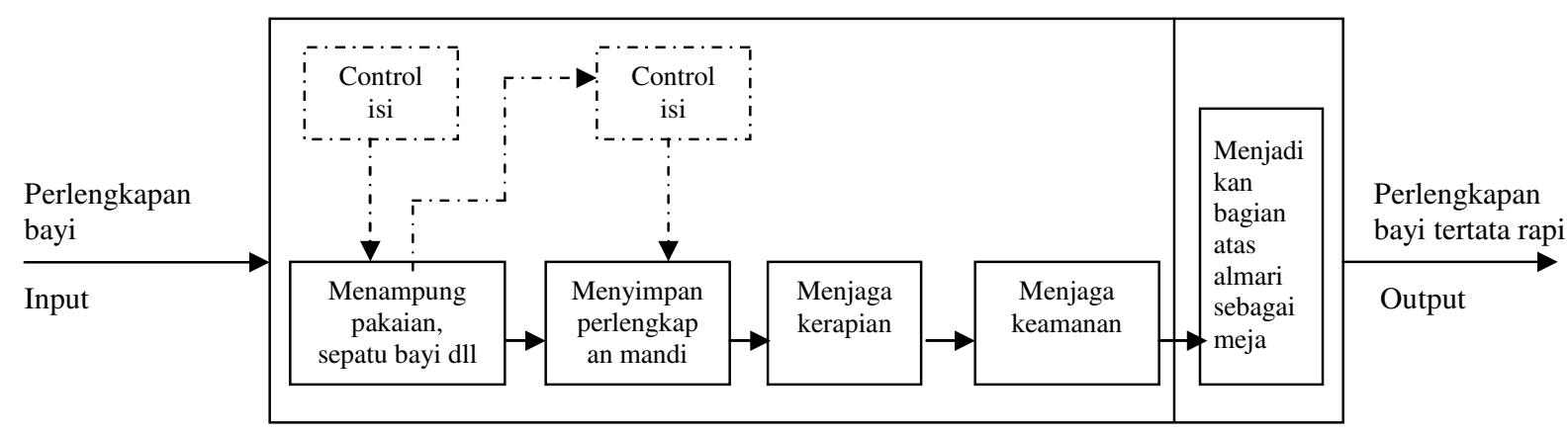

Gambar 3. Sistem White Box dari Almari Pakaian Bayi

\section{Peta Morfologi}

Pada saat brainstorming dilakukan, peneliti menyampaikan beberapa kemungkinan alternatif tentang bagian-bagian almari pakaian bayi yang akan dirancang, seperti ukuran almari, ukuran laci almari, bentuk meja bagian atas almari, letak gantungan handuk dan motif yang digunakan untuk finishingnya. Atas dasar interpretasi terhadap pernyataan kebutuhan konsumen yang disampaikan saat brainstorming, dibuat suatu peta morfologi yang berguna untuk memilih alternatif terbaik dalam merancang produk almari pakaian bayi serbaguna.
Peta ini dibuat untuk membangkitkan alternatif solusi rancangan sebuah produk sekaligus untuk mencari potensi solusi-solusi yang baru (Cross, 1994). Prosedur pembuatan peta morfologi untuk merancang almari pakaian bayi serbaguna ini juga mengacu pada referensi tersebut. Integrasi antara brainstorming dengan peta morfologi memberikan dampak positif bagi proses produksi dalam hal mereduksi biaya perancangan, meningkatkan efisiensi produksi dan menghasilkan produk yang sesuai dengan keinginan konsumen (Rofieq, 2008). 


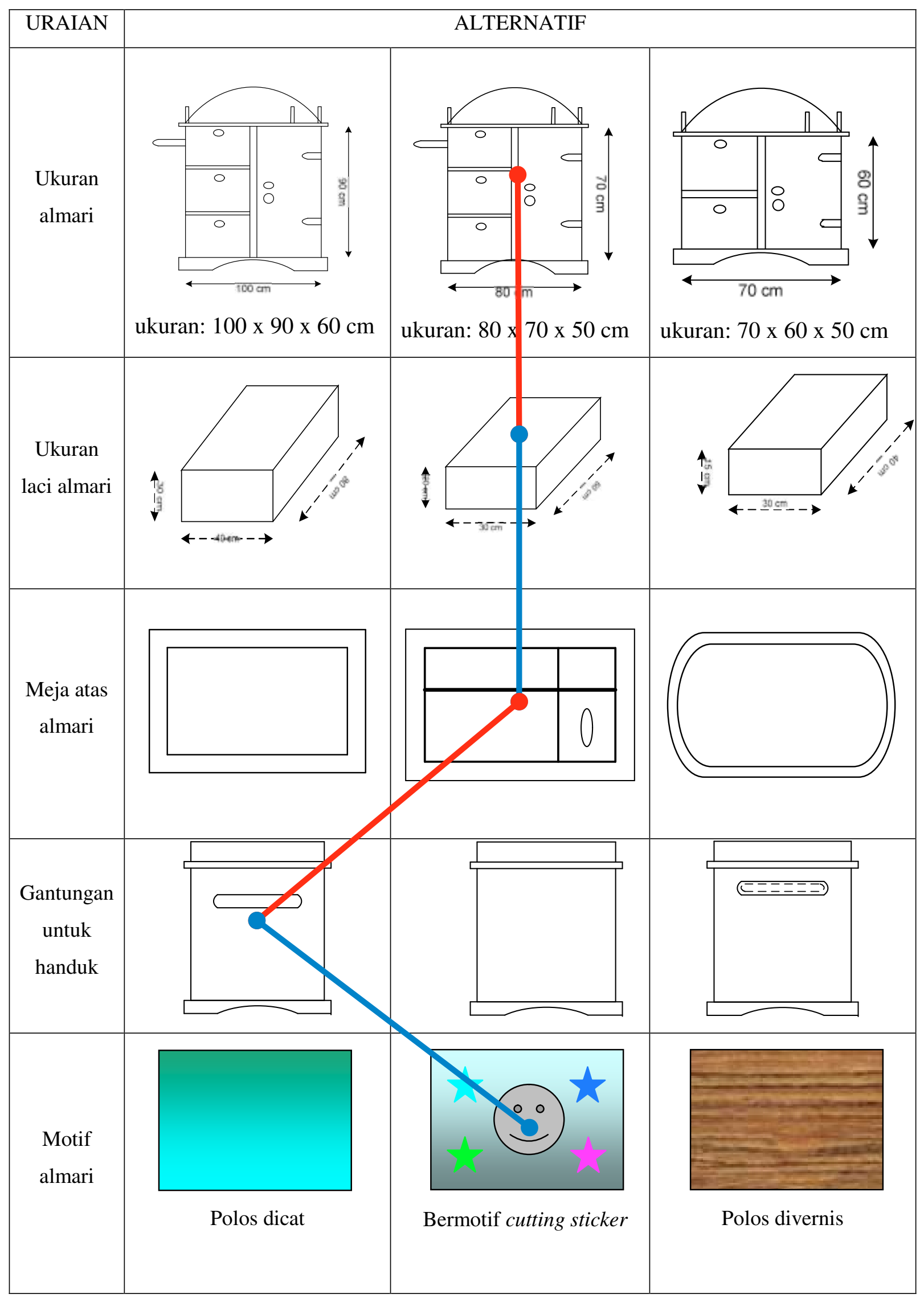

Gambar 4. Peta Morfologi 
Dengan memperhatikan ukuran produk-produk almari pakaian bayi yang ada di pasaran, maka dari penelitian ini dihasilkan ukuran almari pakaian bayi sedang dengan panjang $80 \mathrm{~cm}$, lebar $50 \mathrm{~cm}$ dan tinggi $70 \mathrm{~cm}$, dengan satu pintu almari utama dan tiga buah laci, bagian atas digunakan sebagai meja dan diberi tempat tissue, dilanjutkan dengan memberikan gantungan handuk di bagian samping serta proses finishing/pengecatan dan penempelan cutting sticker dengan foto finished good product almari pakaian bayi serbaguna sebagaimana terlihat pada Gambar 5 dan 6.

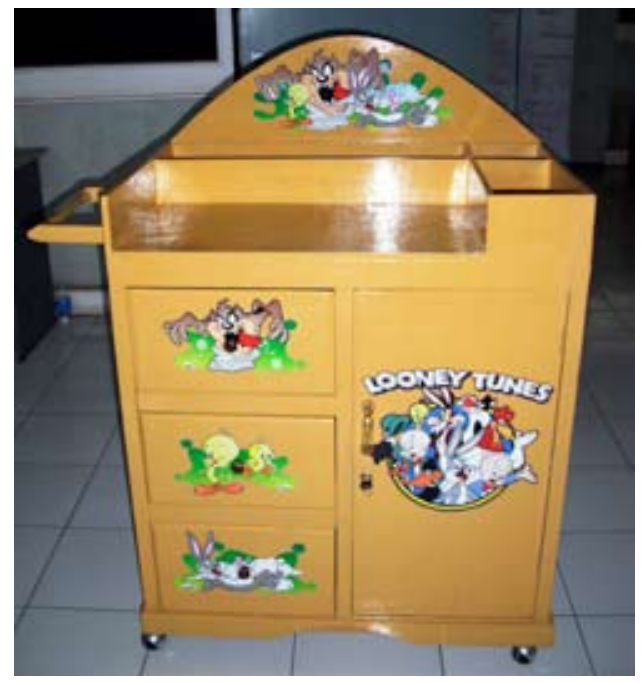

Gambar 5. Finished Good Product Tampak Depan

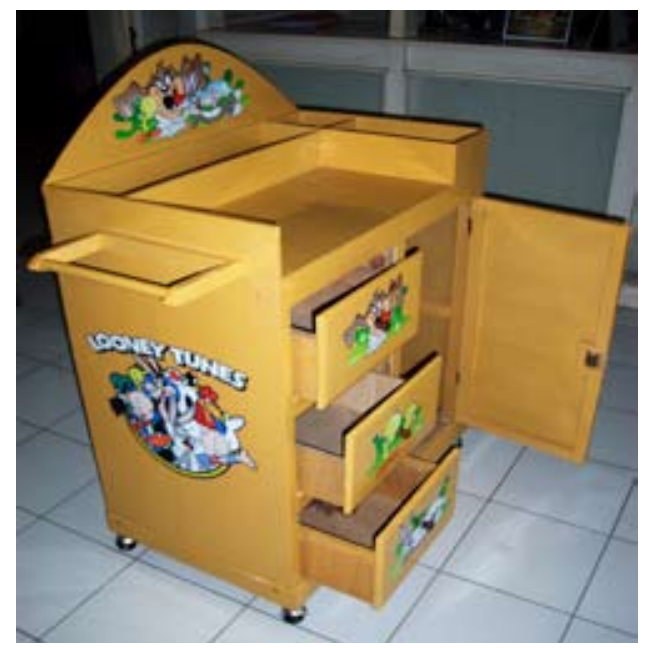

Gambar 6. Finished Good Product Tampak Samping

Dari rancangan almari pakaian bayi serbaguna yang telah dibuat dapat ditunjukkan beberapa kelebihan yang dimiliki, yang ditinjau dari: a. Aspek Fungsional

Dari hasil penelitian ini dapat dibuat desain yang baru sehingga dapat memberikan kemudahan bagi para ibu dalam menyiapkan keperluan bayi, seperti adanya fungsi tambahan yang digunakan dalam almari sehingga para ibu dapat menyimpan pakaian bayi yang cukup banyak dan dapat meletakkan berbagai perlengkapan yang dibutuhkan oleh sang bayi serta dapat membuat susu hangat bayi pada saat diperlukan khususnya di waktu malam.

b. Aspek Struktural

Dengan memperbaiki strukturnya maka almari pakaian bayi serbaguna tersebut dapat digunakan dengan tepat dan sempurna, di antaranya memperbaiki ukuran, bentuk serta kegunaannya. Seperti pada almari pakaian bayi yang baru terdapat gantungan handuk di sampingnya. Pada bagian atas almari pakaian bayi tersebut dapat dijadikan sebagai rak untuk meletakkan berbagai keperluan yang ada.

c. Aspek Lingkungan

Almari pakaian bayi serbaguna yang telah dibuat sangat mudah dalam menggunakan, tidak terlalu memerlukan tempat, mudah dipindahkan di sudut manapun dalam kamar, manis dalam penampilan dengan harga yang terjangkau.

\section{SIMPULAN}

Almari pakaian bayi yang selama ini ada pada umumnya hanya sebagai tempat menyimpan pakaian saja, maka dilakukan pengembangan terhadap almari pakaian bayi ini agar dapat memberi nilai tambah dari aspek fungsionalnya. Pengembangan terhadap nilai manfaat yang dilakukan adalah dengan cara memberikan kunci sebagai pengaman, bagian atas almari yang dapat digunakan sebagai tempat membuat susu atau apabila bayi sudah besar/sekolah maka bagian ini dapat digunakan sebagai meja belajar atau rak buku. Almari ini juga dilengkapi dengan gantungan handuk bayi dan untuk lebih mempercantik penampilannya, almari ini dicat dan ditempeli cutting sticker agar lebih indah dan tahan lama. Dalam merancang suatu produk, selain memperhatikan enam fase pengembangan yakni perancangan, pengembangan konsep, perancangan tingkat sistem, perancangan detail, pengujian dan perbaikan serta produksi, identifikasi terhadap kebutuhan konsumen harus tetap dilakukan karena akan sangat memengaruhi hasil pengembangan produk tersebut. 


\section{DAFTAR PUSTAKA}

Cross, N., 1994. Engineering Design Methods, Strategies for Product Design. John Wiley \& Sons Ltd, Baffins Lane, Chichester, West Sussex PO19 IUD, England.

Inwood, D. and Hammond, J., 1995. Pengembangan Produk. Pustaka Binaman Pressindo, Jakarta.

Kotler, P., 1988. Marketing Management: Analysis, Planning, Implementation and Control. Prentice Hall International Inc, New Jersey.

Rawlinson, J.G., 1986. Berfikir Kreatif \& Brainstorming. Penerbit Erlangga, Jakarta.
Rofieq, M., 2008. Penerapan Metode Quality Function Deployment Guna Meningkatkan Produktivitas Hasil Pengeringan Pisang, Jurnal Penelitian dan Pengabdian Kepada Masyarakat, Vol. XX, No. 1. ISSN: 141-07295.

Ulrich, K.T. and Eppinger S.D., 2001. Perancangan \& Pengembangan Produk. Penerbit Salemba Teknika, Jakarta.

Zaman, S., 2011. Definisi, Tujuan dan Manfaat Teknik Brainstorming, http://www.situsbahasa.info/2011/11/ definisitujuandanmanfaatteknikbrainstor.html. 